\title{
The Competition Law Institutions in the BRICS Countries: Developing Better Institutional Models for the Protection of Market Competition
}

\author{
Alexandr Svetlicinii ${ }^{1} \cdot$ Juan-Juan Zhang ${ }^{1}$
}

Received: 17 October 2016/Accepted: 15 January 2017/Published online: 17 February 2017

(C) Fudan University and Springer Science+Business Media Singapore 2017

\begin{abstract}
The paper provides a comparative overview of the BRICS competition regimes with a special focus on the institutional design of the national competition authorities in these countries. It analyses the institutional design of the competition law authorities in the BRICS countries by looking at their autonomy, resources (financial and human), enforcement powers, technical capacity and workload. The paper represents an academic contribution to the mutual learning and experience sharing in the field of competition law currently pursued by the competition authorities of the BRICS countries with the aim to strengthen their institutional and procedural competition enforcement frameworks.
\end{abstract}

Keywords BRICS · Competition law · National competition authority

\section{Introduction: International Competition Law Agenda and BRICS}

Unlike other legal fields related to international trade, competition law, apart from a few notable exceptions ${ }^{1}$ (Bakhoum and Molestina 2012; Kaczorowska-Ireland 2014), has not been elevated to the supra-national level of regulation. The initial work agenda for the Doha Round negotiations of the World Trade Organization

\footnotetext{
1 There are several examples of the regional competition law frameworks established for the integrated markets such as the European Union, the West African Economic and Monetary Union, the Caribbean Community, the Eurasian Economic Union.
}

Alexandr Svetlicinii

AlexandrS@umac.mo

Juan-Juan Zhang

yb57241@umac.mo

1 Faculty of Law, University of Macau, Avenida da Universidade, Taipa, 999078 Macao SAR, China 
(WTO) foresaw a need to formulate global competition rules, but this plan was subsequently abandoned (WTO 2004). As a result, the current global landscape of competition law regimes can be best described by the terms "universal proliferation" and "global convergence" (Jones 2000; Guzman 2004; Waked 2008; Orlanski 2011). On that background, the rise of the BRICS (Brazil, Russia, India, China, South Africa) as a global economic and political alliance attracted significant attention to the national competition law regimes of these countries. Unlike many regional blocks, the BRICS countries lack geographic connection, shared language and their history of cultural, economic, political and social developments reflect many more differences than common features. Despite these differences the significance of competition policy in these large globalized economies prompted a certain degree of co-operation and experience sharing amongst them. This dialogue was carried out at the biennial BRICS international competition conferences: in Kazan (Russia) in 2009, in Beijing (China) in 2011, in New Delhi (India) in 2013, and the most recent one in Durban (South Africa) in 2015. During their meeting in Durban, the heads of the BRICS national competition authorities (NCAs) issued a joint statement announcing their decision to conclude a memorandum of understanding "in the field of competition policy to strengthen the cooperation and coordination between the BRICS Competition Authorities". 2 The Memorandum was concluded on 19 May 2016 in St Petersburg (Russia).

The American antitrust scholar William Kovacic underlined the significance of studying BRICS experience in competition enforcement in the following way: "The BRICS nations supply informative contexts in which to analyze the establishment of competition policy systems at the national level and derive larger lessons about superior approaches for other jurisdictions. They provide an opportunity for older and newer competition systems to revisit basic questions about the institutional foundations for successful implementation, the life cycle of antitrust regimes, and the measurement of effectiveness" (Kovacic 2012: 324-325). Up till now, the competition law practitioners have focused their attention primarily on the national competition regimes of BRICS jurisdictions (Emch et al. 2012), while academics have engaged in the comparative analysis of the enforcement practices in the BRICS countries (Afrika and Bachmann 2011; Belikova 2016; Sharma 2016; Jenny and Katsoulacos 2016). At the same time, little attention has been accorded to the potential contribution of BRICS to the development of good governance structures in the field of competition enforcement as well as their potential role as trend-setters for the design of institutional frameworks for competition enforcement in the emerging economies ${ }^{3}$ and new competition law regimes in general.

The institutional design and procedural tools employed by the NCAs around the world have been on the radar of both policy makers and academic community alike.

\footnotetext{
2 Joint Statement of the Heads of BRICS Competition Authorities (13 November 2015), http://www. compcom.co.za/wp-content/uploads/2016/05/JOINT-STATEMENT-OF-THE-HEADS-OF-BRICSCOMPETITION-AUTHORITIES.pdf.

3 In its 2016 edition of its World Development Indicators, the World Bank abandoned the terminological distinction between the developed and developing countries in light of introducing Sustainable Development Goals that have replaced the Millennium Development Goals. See http://blogs.worldbank. org/opendata/2016-edition-world-development-indicators-out-three-features-you-won-t-want-miss.
} 
For example, the Global Administrative Law Competition Project at the New York University School of $\mathrm{Law}^{4}$ led by Fox and Trebilcock resulted in a comparative study of the procedures applied by the NCAs in the major antitrust jurisdictions. ${ }^{5}$ The authors of the country studies have focused on the following aspects of the NCAs' activity: institutional design, mandate, due process and rights of defense, agency performance, and judicial review (Fox and Trebilcock 2013). In 2009, the Institute for Consumer Antitrust Studies at Loyola University of Chicago Law School hosted an international symposium addressing the institutional design and performance of the NCAs (Waller 2010). The OECD Competition Committee held roundtable events focused on institutional design of NCAs in 2003, 2014 and 2015, where the stakeholders discussed goals, functions and organization of the NCAs worldwide (Jenny 2016).

Despite the development of the best practices on various matters of competition law and policy (OECD 2005; ICN 2016; Alemani et al. 2016), the ultimate structure and procedural tools employed by the NCA have been framed primarily by the domestic circumstances. As remarked by Eleanor M. Fox in her paper on antitrust and institutional design, "context is a major determinant of institutional design" (Fox 2010: 488). Antitrust scholar Michal Gal argued that like the legal transplants of substantive and procedural rules, the institutional design that is optimal for one jurisdiction does not guarantee the achievement of the same beneficial results in another as it may not be wellsuited for the special characteristics of the transplanting jurisdiction (Gal 2010: 419). For example, although China has adopted EU-modelled competition rules, the differences in the institutional design of competition enforcement authorities are significant and the comparative competition law scholars have argued that the value learning from the European experiences will be rather limited (Cengiz 2013: 295).

The present paper aims to contribute to the above mentioned academic discourse on the institutional design of NCAs by addressing the specifics of the NCAs in the BRICS countries. This comparative review should also aid to the mutual learning and experience sharing in the field of competition law currently pursued by the competition authorities in the BRICS countries with the aim to strengthen their institutional and procedural competition enforcement frameworks. The paper is structured as follows. Section 2 introduces the historical background that led to the establishment and continuous reform of the competition law enforcement institutions in the BRICS countries. Section 3 addresses the current institutional structures developed by the BRICS countries for the enforcement of their national competition law regimes. Finally, Sect. 4 analyses the enforcement powers and technical capacity of the NCAs of the BRICS countries to provide a better understanding of their enforcement performances.

\footnotetext{
${ }^{4}$ Global Administrative Law Project, http://www.iilj.org/gal/.

5 When addressing the BRICS countries, the project covered only China and South Africa due to the fact that Brazil was undergoing a substantial reform of its competition legislation, while Indian antitrust had seen virtually no enforcement.
} 


\section{Historical Development of the Competition Law Institutions in the BRICS Countries}

\subsection{Brazil}

In 1962, Brazil adopted its first anti-monopoly law $^{6}$ and established its NCA-the Administrative Council for Economic Defense (known by its Portuguese acronym CADE (Conselho Administrativo de Defesa Econômica), which initially was not complemented by a consistent competition policy and effective enforcement powers (Casagrande 2014: 2). In 1994, the new Federal Law No. 8,158 reformed the competition enforcement system, which now included the Secretariat of Economic Law within the Ministry of Justice (SDE-Secretaria de Direito Econômico), the Secretariat of Economic Monitoring within the Ministry of Finance (SEAESecretaria de Acompanhamento Econômico), and the CADE. ${ }^{7}$ These three agencies with overlapping enforcement responsibilities created significant backlogs in merger review and anti-competitive conduct investigations (Zarzur et al. 2015: 9), which prompted the calls for further reform.

The current Brazilian competition protection system entered into force on 30 May 2012 when the Brazilian Competition $\mathrm{Act}^{8}$ consolidated the institutional structures for competition enforcement (Botta 2010; Schaeffer et al. 2011a, b; Moraes 2011). It was regarded as "a historical and decisive milestone for the improvement of the Brazilian competition policy" (De Carvalho 2012: 3). The three former institutions were reduced to two by integrating SDE into the new CADE with streamlined decision-making processes, significantly reduced the backlog in investigations, and added a number of notable organizational improvements. The reformed CADE has been praised for "leading the way to faster, more efficient and more effective enforcement and the consolidation of a competition culture in Brazil" (De Carvalho 2015: 40). The CADE is currently composed of the General Superintendence, with one General Superintendent and two Deputy Superintendents ${ }^{9}$; the Administrative Tribunal for Economic Defense, with a president and six commissioners ${ }^{10}$; the Department of Economic Studies. ${ }^{11}$

\subsection{Russian Federation}

The anti-monopoly system of the Russian Federation was set up in early 1990s on the background of the country's economic transition. In July 1990, the State Committee for Anti-Monopoly Policy and the Support of New Economic Structures was established, ${ }^{12}$ which became the first anti-monopoly enforcement authority. In 1997,

\footnotetext{
${ }^{6}$ Federal Law No. 4,137 of 10 September 1962.

7 Federal Law No. 8,884 of 11 June 1994.

8 Federal Law No. 12,529 of 29 May 2012.

9 Art. 12, Federal Law No. 12,529 of 29 May 2012.

${ }^{10}$ Id., Art. 6.

11 Id., Art. 5.

12 On Republican Ministries and State Committees of the RSFSR, the Law of Russian Soviet Federative Socialist Republic, 14 July 1990.
} 
the Committee was renamed into the State Anti-Monopoly Committee. ${ }^{13}$ In 1998, the functions of the State Anti-Monopoly Committee were transferred to the Ministry for Anti-Monopoly Policy and Support to Entrepreneurship, which was also abolished in March 2004 and the current Federal Anti-Monopoly Service (known by its Russian acronym FAS-Federal'naya Antimonopol'naya Sluzhba) was established. ${ }^{14}$

The new Federal Law on Protection of Competition adopted on 26 July $2006^{15}$ was considered "groundbreaking because it introduced many new concepts and institutions, as well as prior antitrust rules and procedural issues subjected to a substantial revision" (Artemyev 2012: 57). Currently the FAS includes 30 departments $^{16}$ and 85 territorial offices (FAS 2014b), as well as the crossdepartmental public consultation committee and expert committee (FAS 2015).

\subsection{India}

In 1969, India adopted its first anti-monopoly law: the Monopolies and Restrictive Trade Practices Act (MRTP Act), ${ }^{17}$ which established the MRTP Commission which ceased to exist in 2009. The current Competition Act was adopted by the Indian legislature in December $2002^{18}$ and in the following year, the Competition Commission of India (CCI) was established. In 2007, the Competition (Amendment) $\mathrm{Act}^{19}$ further specified the structure of the CCI, the requisite qualifications and enforcement powers of its officers. The CCI was effectively established in 2009. The CCI consists of a Chairperson and six commissioners. Additionally, the Office of the Secretary and the Director General was created to assist the Chairperson. ${ }^{20}$ As a newly established institution, the CCI recognized the need for capacity building: "the CCI currently faces the need to accumulate this understanding, as well as to ensure that such knowledge is not restricted to just a few individuals" (Gaur 2012: 103).

\subsection{China}

China was the latest country to establish its anti-monopoly regime among the BRICS—-the current Anti-Monopoly Law was promulgated on 30 August $2007 .^{21}$

\footnotetext{
13 On perfection of the structure of the federal bodies of executive power, the Decree of the President of the Russian Federation No. 249, 17 March 1997.

14 On the System and Structure of the Federal Executive Authorities, the Decree of President of the Russian Federation No. 314, 9 March 2004.

15 Federal Law No. 135-FZ of 26 July 2006.

16 See FAS structure at http://en.fas.gov.ru/about/structure/.

17 Monopolies and Restrictive Trade Practices Act, Act No. 54 of 1969.

18 Competition Act 2002, Act No. 12 of 2003, 13 January 2003, available at: http://www.cci.gov.in/sites/ default/files/cci_pdf/competitionact2012.pdf.

19 The Competition (Amendment) Act, Act No. 39 of 2007, 10 September 2007, available at: http://dpal. kar.nic.in/Central\%20Acts\&Ordinance\%20PDF/Act\%2039\%20of\%202007\%20PR-90.pdf.

20 Available at: http://www.cci.gov.in/organogram.

21 Anti-Monopoly Law of the People's Republic of China, Order No. 68 of the President of the People's Republic of China, Standing Committee of the National People's Congress, 30 August 2007.
} 
The Anti-Monopoly Commission of the State Council, in charge of organizing, coordinating and guiding anti-monopoly work, assigned competition enforcement tasks to the following three agencies: the Ministry of Commerce (MOFCOM), ${ }^{22}$ the National Development and Reform Commission (NDRC) ${ }^{23}$ and the State Administration for Industry and Commerce (SAIC). ${ }^{24}$ Subsequently, each of the above mentioned agencies designated a specialized bureau responsible for the enforcement of anti-monopoly law. The above mentioned anti-monopoly authorities have multitier hierarchical structures that spread from the central offices in Beijing down to provincial and city offices. This multi-tier and multi-agency organizational structure has led to various conflicts and inconsistencies in the enforcement of AntiMonopoly Law (Round and Lin 2012: 2).

\subsection{South Africa}

Among the BRICS nations, South Africa was the first country to establish its national competition law regime, which should be traced back to 1955 Regulation of Monopolistic Conditions Act. ${ }^{25}$ According to the 1955 Act, the Board of Trade and Industry was charged with investigating conduct, recommending remedies, and negotiating and supervising compliance. However, the Board had no independent powers, neither of investigation nor relief. The decision-making was handled by the Minister of Trade and Industry. The legal remedies were prospective only which included orders to withdraw from restrictive agreements and to correct their consequences (Wise 2004: 11). In 1979, the Maintenance and Promotion of Competition $\mathrm{Act}^{26}$ was adopted, which created the Competition Board appointed by the Minister of Trade and Industry with the investigation powers exercised on its own initiative.

In 1998, the third competition law of South Africa entered into force-the Competition Act, ${ }^{27}$ which was substantially revised in 2009. The Competition Act set up three institutions: the Competition Commission, the Competition Tribunal and the Competition Appeal Court to be directly involved in its enforcement. The Competition Commission of South Africa consists of one commissioner and two deputy commissioners ${ }^{28}$ with eight administrative units. ${ }^{29}$ South Africa adopted a bifurcated agency model, where the specialized agency carries out investigative functions and brings the case before the specialized tribunal for adjudication (Davis and Granville 2013). The South African judiciary has continuously moved away from the formalistic interpretation of the Competitions Act and recognized the

\footnotetext{
22 Anti-Monopoly Bureau of the MOFCOM, http://english.mofcom.gov.cn/departments/fldj2/.

23 The Bureau of Price Supervision and Anti-Monopoly of the NDRC, http://jjs.ndrc.gov.cn/.

24 The Anti-Monopoly and Anti-Unfair Competition Enforcement Bureau of the SAIC, http://www.saic. gov.cn/english/aboutus/Departments/.

25 Act No. 24 of 1955.

26 Act No. 96 of 1979.

27 Act No. 89 of 1998.

28 Art. 19, Competition Act 1998 of South Africa.

29 Available at: http://www.compcom.co.za/.
} 
Table 1 Comparison of the institutional models of NCAs in the BRICS

\begin{tabular}{llllll}
\hline Country & Autonomy & & \multicolumn{2}{l}{ Number } \\
\cline { 2 - 3 } \cline { 5 - 5 } & Stand-alone agency & Subsidiary agency & & one agency & Many agencies \\
\hline Brazil & $\checkmark$ & & & $\checkmark$ \\
Russia & $\checkmark$ & & $\checkmark$ & $\checkmark$ \\
India & $\checkmark$ & $\checkmark$ & & $\checkmark$ \\
China & & & $\checkmark$ & \\
South Africa & $\checkmark$ & & & \\
\hline
\end{tabular}

transformative role of the competition policy in ensuring equitable participation of all sections of population in the economic activity (Ramburuth 2012).

\section{Institutional Design of the National Competition Authorities in the BRICS Countries}

For the purpose of simplification, the following institutional models for competition enforcement can be generally distinguished: bifurcated judicial model (NCA with investigative function), bifurcated agency model (NCA with investigative and enforcement functions), integrated agency model (NCA with investigative, enforcement, adjudication functions) (Trebilcock and Iacobucci 2010: 459-464). Kovacic and Hyman distinguish several models of the institutional designs of the national competition enforcement authorities according to different factors. One of such factors is autonomy, which allows to distinguish the Stand-Alone Agency and Subsidiary Agency models. Stand-Alone Agency is a self-contained body that has greater ability to establish a distinct identity and brand, and also to respond to changing circumstances without the need to "run things up the ladder" or to coordinate policy with other units in the organization of which it is a part (Kovacic and Hyman 2012: 531). Subsidiary Agency refers to the competition enforcement agency positioned within a larger entity.

Another distinction is based on the number of the enforcement agencies. Kovacic and Hyman distinguished One Agency and Many Agencies models. The former means to give a single public institution an exclusive enforcement authority while the latter refers to two or more public enforcement agencies at the same level of government or multiple levels of government (i.e. central and local) (Kovacic and Hyman 2012: 532). Table 1 applies this categorization to the competition authorities in the BRICS countries.

The NCA of Brazil is formed by one General Superintendent and two Deputy Superintendents. The General Superintendent is appointed by the President of the Republic, after being approved by the Federal Senate for a 2-year term with the possibility of re-appointment. The removal of these officers may only occur by means of a decision made by the Federal Senate upon request of the President of the Republic, in view of an undisputable criminal conviction for intentional crimes, or 
disciplinary proceedings as determined by law. ${ }^{30}$ According to the new Competition Act of Brazil, CADE's own revenues are comprised of: (1) procedural fees; (2) the remuneration for services; (3) the funds originating from the Government; (4) other entities or organizations; (5) donations and grants, etc.; (6) the sale or rental of real estate and personal property; (7) the sale of publications, technical materials, data and information; (8) the sums collected from applications from the financial market; (9) any other income such as fines. ${ }^{31}$ Thus, besides the funds from the government, the CADE has access to other financial resources, which can enhance its financial independence from the executive.

The Russian FAS stands out in the governmental hierarchy as it combines the functions of a ministry and of a service (Sushkevich 2004: 1). Its head is appointed by an act of the Government and reports to the Prime Minister, as well as to the Deputy Prime Minister with responsibility for the subject area and to the Government as a whole (OECD 2013: 90). For that reason, the authority of the Russian anti-monopoly enforcement authority is very high. The FAS's position as a part of the Government provides it with the ability to comment on all draft laws and draft acts of the Government, as well as to participate in policy development. According to the FAS, its ability to participate in these processes is one of its most important tools to promote and protect competition (OECD 2013: 90). Although Russian competition enforcement authority has central offices and territorial branches, the latter are not easily influenced by other institutions and local governments because of their independent personnel and finances. The expenses of the central and territorial offices of the FAS are covered from the federal budget (FAS 2012: 39, 2013: 32, 2014a, b: 42, 2015: 29).

The Indian CCI consists of a Chairperson and between two and six other commissioners appointed by the Central Government. ${ }^{32}$ The Central Government may, by order, remove the Chairperson or any other commissioner from office according to legal causes. ${ }^{33}$ The finances of the CCI are provided by the Central Government, ${ }^{34}$ therefore, the budget proposal and financial report should be submitted to the Central Government. ${ }^{35}$

In China, the heads of the MOFCOM, the NDRC and the SAIC are appointed by the National People's Congress upon nomination by the Prime Minister. ${ }^{36}$ Although the financial resources of the Chinese anti-monopoly enforcement authorities may come from a variety of sources, the government's financial allocation accounted for 94.02\% of their respective budgets in 2015 (MOFCOM 2016; NDRC 2016; SAIC 2016) (Table 2).

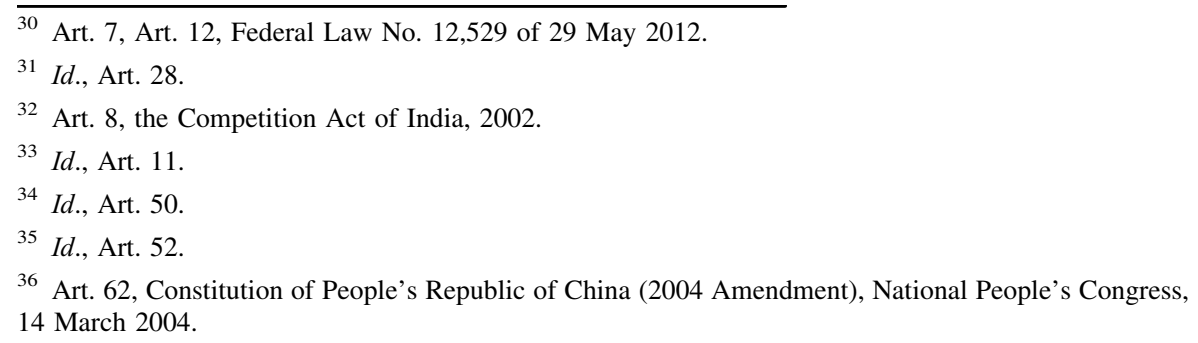


Table 2 The share of the government's financial contribution to the budget of Chinese anti-monopoly enforcement authorities (2015)

\begin{tabular}{lcrl}
\hline $\begin{array}{l}\text { Anti-monopoly } \\
\text { enforcement } \\
\text { authority }\end{array}$ & $\begin{array}{l}\text { The government's financial } \\
\text { allocation (ten thousand } \\
\text { RMB) }\end{array}$ & $\begin{array}{l}\text { Total budget (ten } \\
\text { thousand RMB) }\end{array}$ & $\begin{array}{l}\text { Percentage of government's } \\
\text { funds in the total budget (\%) }\end{array}$ \\
\hline SAIC & $72,662.99$ & $90,078.07$ & 80.67 \\
NDRC & $107,915.66$ & $163,848.86$ & 65.86 \\
MOFCOM & $2,204,328.26$ & $2,282,682.75$ & 96.57 \\
Total & $2,384,906.91$ & $2,536,609.68$ & 94.02 \\
\hline
\end{tabular}

Despite the fact that the MOFCOM, the NDRC, and the SAIC belong to the rank of ministries, the competition enforcement tasks are performed by subordinate bureaus, resulting in the lower administrative rank. Because of the vast territory and large population, the competition enforcement is also organized through the local branches of the specified agencies. This has led to a certain degree of dependence on the local governments in aspects of finance and personnel affairs. The distribution of the enforcement tasks between several institutions and the current status of China's administrative law and regulatory practices were mentioned among the major reasons for lower effectiveness of antitrust enforcement in that jurisdiction ( $\mathrm{Su}$ and Wang 2013; Gao and Wan 2013). As noted by Chinese antitrust practitioners, although the procedural fairness of the public administrative enforcement may not be aligned with the standards adopted in the Western jurisdictions, the Chinese NCAs comply with the current system of China's administrative law (Deng 2016).

According to the 1998 Competition Act, the Competition Commission of South Africa is independent and subject only to the Constitution, and the law must be impartial and perform its functions without fear, favor or prejudice. Public authorities must assist the Competition Commission to maintain its independence and impartiality, and to effectively carry out its powers and duties. ${ }^{37}$ In terms of its budget, the Competition Commission is financed by: (1) funds that are appropriated by the Parliament for the Commission; (2) fees payable to the Commission under Competition Act; (3) income derived by the Commission from its investment and deposit of surplus funds; (4) funds received from other sources. ${ }^{38}$ The Commissioner is the highest administrative officer of the Competition Commission, appointed by the Minister for a term of 5 years. ${ }^{39}$ Supported by the large amount of merger fees, the Commission is able to recruit a substantial number of new staff (OECD 2003: 38).

\footnotetext{
37 Art. 20, Competition Act of South Africa, No. 89 of 1998.

${ }^{38}$ Id., Art. 40.

${ }^{39}$ Id., Art. 22.
} 
Table 3 Powers of NCAs in the BRICS

\begin{tabular}{llllll}
\hline $\begin{array}{l}\text { Extent of competence of competition enforcement } \\
\text { authority }\end{array}$ & Brazil & Russia & India & China & $\begin{array}{l}\text { South } \\
\text { Africa }\end{array}$ \\
\hline Agreements restricting competition & $\checkmark$ & $\checkmark$ & $\checkmark$ & $\checkmark$ & $\checkmark$ \\
Abuse of dominant position & $\checkmark$ & $\checkmark$ & $\checkmark$ & $\checkmark$ & $\checkmark$ \\
Merger control & $\checkmark$ & $\checkmark$ & $\checkmark$ & $\checkmark$ & $\checkmark$ \\
Administrative monopoly & & $\checkmark$ & & $\checkmark$ & \\
Unfair competition & & $\checkmark$ & & $\checkmark$ & \\
Public procurement & $\checkmark$ & & & \\
Advertising & & $\checkmark$ & & & \\
\hline
\end{tabular}

\section{Enforcement Powers and Technical Capacity of the National Competition Authorities in the BRICS Countries}

Although different from country to country, the powers of the NCA normally include the following: (1) the investigation powers (the anti-monopoly enforcement authority has the power to investigate whether the conduct of market participants is in compliance with competition law); (2) the review and approval powers (this mainly concerns the review of agreements (or decisions) concerning economic concentrations (merger control); (3) the power to impose administrative penalties; (4) the power to impose compulsory administrative measures; (5) the power of rulemaking (the NCA has the power to enact administrative rules in the scope of the provisions of competition law to guide and promote the market competition).

The competition enforcement authorities of the BRICS countries all have the basic functions mentioned above. Nevertheless, the extent of competences is different. The table below shows the extent of competence of Russian FAS and Chinese antimonopoly authorities is the widest, which is characteristic of the national economy with substantial state involvement. All competition enforcement authorities of the BRICS countries have the power to prohibit and prosecute anti-competitive agreements, abuse of dominant position and to enforce merger control (Table 3).

As transition economies, both Russia and China are facing the difficult task of prohibiting the abuse of administrative power that restricts market competition. For example, the current Russian Federal Law on Protection of Competition prohibits acts, actions (inactions), agreements, concerted practices of the federal executive authorities, public authorities of the subjects of the Russian Federation, bodies of local self-government, other bodies or organizations exercising the functions of the above-mentioned bodies, as well as public extra-budgetary funds and the Central Bank of the Russian Federation that restrict competition. ${ }^{40}$ Similarly, China's AntiMonopoly Law prohibits abuses of administrative power to eliminate or restrict competition: imposing discriminative charges and/or technical requirements, abusing administrative licensing powers, setting barriers for commodities outside certain geographic markets, etc. ${ }^{41}$

\footnotetext{
${ }^{40}$ Chapter 3, Federal Law No. 135-FZ.

${ }^{41}$ Anti-Monopoly Law, Chapter V.
} 
Table 4 NCAs in the BRICS (2014) Source: GCR (2015), CCI 2015, CADE (2015), FAS (2014a, 2015)

\begin{tabular}{lrlr}
\hline Country & Staff & Budget (EUR million) & Total cases \\
\hline Brazil & 366 & 10.2 & 581 \\
Russia & 3038 & 35.8 & 4791 \\
India & 156 & 5.5 & 167 \\
China & $100^{\mathrm{a}}$ & 320.25 (MOFCOM 2014; SAIC 2015; NDRC 2014) & $28^{\mathrm{c}}$ \\
South Africa & 188 & 22 & 437
\end{tabular}

${ }^{\mathrm{a}}$ It was not possible to obtain official statistics of staff numbers of the anti-monopoly enforcement authorities in China. The official press service has reported that there are less than 100 staff in the three enforcement authorities, among which only half of them are involved in anti-monopoly work on a fulltime basis. See press release available at: http://www.china.com.cn/zhibo/2014-09/11/content_33487367. htm. Accessed 10 December 2016

${ }^{b}$ The total budget of the three anti-monopoly authorities combined is large, but in fact the amount to be spent on anti-monopoly enforcement is relatively small. Overall, there are 45 departments in MOFCOM, 30 in SAIC and 28 in NDRC, while the anti-monopoly enforcement work is carried out by a single department in each of the above mentioned agencies. There is no special illustration on the budget concerning anti-monopoly affairs in the budget records of the three anti-monopoly enforcement authorities, which have multiple regulatory and supervisory functions besides anti-monopoly enforcement

c According to unofficial and incomplete statistics, in 2014, the merger control cases accepted by MOFOM were 246; cases accepted by NRDC were 22, among which the anti-competitive agreements were investigated in 19 cases; abuse of the dominant market position in two cases, abuse of the administrative power in one case; cases accepted by SAIC were 17, among which anti-competitive agreements were concerned in four cases; abuse of the dominant market position were investigated in 13 cases. Available at: http://www.weibo.com/p/1,001,603,808,585,187,522,510?from=page_100505_ profile $\& w v r=6 \& \bmod =$ wenzhangmod

Considering the relationship between the closely related unfair competition and anti-monopoly enforcement, there are three institutional models in the BRICS countries. The first model is single anti-monopoly enforcement model, where the anti-monopoly legislation does not contain unfair competition rules and the competition authority is not charged with their enforcement. Brazil, India and South Africa have adopted this model. The second model is adopted by the Russian Federation, where the FAS is the enforcement authority for both anti-monopoly and unfair competition rules. China has created the third model. Although China has, respectively, regulated the anti-monopoly and unfair competition rules in two distinct laws, the enforcement authority has been consolidated and the SAIC is responsible for the enforcement of both sets of rules.

The assessment of the technical capacity of the BRICS competition authorities can take into account a variety of factors including the annual budget, the number of personnel and their workload. Table 4 below reveals a great disparity in the financial and human resources available for the competition enforcement authorities in the BRICS countries. Russian FAS appears as the largest competition authority amongst the BRICS countries both in terms of budget and staff. This is largely due to the numerous regulatory tasks carried out by this agency as well as the centralized funding of its 85 territorial offices. South Africa, the smallest of the BRICS nations, allocates more financial resources and personnel to its competition authority than India. Brazil's competition authority, on the other hand, with a relatively modest 
Table 5 Comparison of the personnel structures of NCAs in the BRICS in 2014. Source: GCR (2015), CCI (2015)

\begin{tabular}{|c|c|c|c|c|}
\hline Country & Total staff & $\begin{array}{l}\text { Administrative } \\
\text { staff }\end{array}$ & $\begin{array}{l}\text { Non-administrative } \\
\text { staff (case handlers) }\end{array}$ & $\begin{array}{l}\text { Percentage of non- } \\
\text { administrative staff } \\
\text { (case handlers) }(\%)\end{array}$ \\
\hline Brazil & 366 & 149 & 96 & 26.23 \\
\hline Russia & 3038 & 2145 & 1777 & 58.49 \\
\hline India & 156 & 91 & 91 & 58.33 \\
\hline China (only central office) & Approx. 100 & Approx. 50 & Approx. 50 & 50.00 \\
\hline South Africa & 188 & 131 & 115 & 61.17 \\
\hline
\end{tabular}

budget employs more people than India, China or South Africa. The number of personnel is in direct correlation with the workload of the respective competition enforcement agencies: Russian and Brazilian competition authorities handle more cases per person than India, China, or South Africa.

A more detailed examination of the personnel structure in the BRICS competition enforcement authorities indicates that the number of officials dealing with the competition law cases directly (case handlers) is almost equal to the number of administrative staff employed by the respective agencies. Brazil is a notable exception, its case handlers account only for $26 \%$ of the total number of personnel. Nevertheless, as shown above, the Brazilian competition authority with relatively modest funding and low percentage of case handlers has managed to investigate more cases than its counterparts in India, China and South Africa (Table 5).

The number of personnel available for competition enforcement activities affects not only the number of cases but also their duration. For example, the following table illustrates the average workload of the merger control officers in the BRICS competition authorities, as well as the average length of the in-depth merger review procedures. The Russian FAS employs the largest number of case handlers-1777. As a result, with a relatively modest workload per officer the Russian FAS achieves the fastest rate of merger review amongst the BRICS countries. Despite the highest workload per officer, the Brazilian competition authority managed to achieve an average of 77-day merger review process thus surpassing India, China and South Africa in this respect. The Chinese MOFCOM, which employs more officers than Brazil, India and South Africa lags behind in the efficiency, which makes its average length of in-depth merger review the longest amongst the BRICS countries-300 days (Table 6).

\section{Concluding Remarks}

The above overview of the institutional structures established in the BRICS countries for the protection of market competition reveals a substantial diversity in the institutional design, autonomy, competence and technical capacity of the competition authorities. Brazil and South Africa have established their competition regimes relatively early and have passed a long way in reforming and strengthening 
Table 6 Merger cases resolved by NCAs in the BRICS in 2014. Source: GCR (2015), CCI (2015), USChina Business Council (2014)

\begin{tabular}{lccll}
\hline Country & $\begin{array}{l}\text { Number of } \\
\text { case handlers }\end{array}$ & $\begin{array}{l}\text { Merger control } \\
\text { cases }\end{array}$ & $\begin{array}{l}\text { Average length of } \\
\text { an in-depth merger } \\
\text { review }\end{array}$ & $\begin{array}{l}\text { Cases decided } \\
\text { per officer }\end{array}$ \\
\hline Brazil & 96 & 423 & 77 & 4.41 \\
Russia & 1777 & 2246 & 45 & 1.26 \\
India & 91 & 94 & 168 & 1.03 \\
China & 165 & 246 & 300 & 1.49 \\
South Africa & 115 & 358 & 64 & 3.11 \\
\hline
\end{tabular}

their institutional structures. In Brazil, the competition authorities have been reorganized and consolidated several times, while in South Africa the Competition Commission has gradually acquired institutional autonomy and enforcement powers. In Russia, the competition authority has been elevated to the rank of ministry and accorded substantial resources and manpower to exercise a multitude of competition protection and regulatory tasks. In India, the CCI has started its enforcement activity relatively recently and it has not yet acquired the technical capacity and resources required for a more significant workload. China has adopted a unique multiple agency model with the three agencies handling specific forms of anti-competitive conduct under the Anti-Monopoly Law.

As suggested by William Kovacic, the diversity of the BRICS countries in the field of competition law enforcement provides an opportunity for the emerging competition law regimes to revisit basic questions of the institutional foundations and implementation of their national competition laws (Kovacic 2012: 35). Therefore, the viability of the institutional structures for competition enforcement in the BRICS countries as well as their ability to cooperate, share enforcement experience and expertise will be decisive factors in the BRICS countries' ability to develop their own "BRICS way" of dealing with competition law enforcement. The recently signed Memorandum of Understanding provides a formal ground for further development of inter-institutional cooperation of the NCAs of the BRICS countries. It remains to be seen whether and how this cooperation could reinforce the national competition regimes of the BRICS economies in line with the declared objectives to foster inter-BRICS trade and investments.

Acknowledgements The authors acknowledge the support from the University of Macau Multi-Year Research Grant MYRG2015-00071-FLL "EU competition rules as legal transplants in the domestic legal orders: policy tools for market regulation and protection of competition". The authors are thankful to Yijia Jing, Jose Antonio Puppim de Oliveira, and participants of the International Symposium on Development and Governance in the BRICS hosted at Fudan University in Shanghai (China) on 24-25 September 2016 for their valuable comments on the earlier draft of this paper.

\section{References}

Administrative Council for Economic Defense (CADE). 2015. Annual report on competition policy developments in Brazil. OECD Directorate for Financial and Enterprise Affairs, Competition Committee, DAF/COMP/AR(2015)19 (19 May 2015). 
Afrika, Sasha-Lee, and Sascha-Dominik Bachmann. 2011. Cartel regulation in three emerging BRICS economies: Cartel and competition policies in South Africa, Brazil, and India-a comparative overview. The International Lawyer 45 (4): 975-1003.

Alemani, Enrico, Caroline Klein, Isabell Koske, Cristiana Vitale, and Isabelle Wanner. 2016. New Indicators of Competition Law and Policy in 2013 for OECD and Non-OECD Countries. In Competition law enforcement in the BRICS and in developing countries, ed. Frederic Jenny and Yannis Katsoulacos, 59-133. Springer.

Artemyev, Igor. 2012. Russia: Regulator's Introduction. In Competition Law in the BRICS Countries, ed. Adrian Emch, Jose Regazzini, and Vassily Rudomino, 57-66. Alphen an den Rijn: Kluwer Law International.

Bakhoum, Mor, and Julia Molestina. 2012. Institutional Coherence and Effectiveness of a Regional Competition Policy: The Case of the West African Economic and Monetary Union (WAEMU). In Competition policy and regional integration in developing countries, ed. Josef Drexl, Mor Bakhoum, Eleanor M. Fox, Michal S. Gal, and David J. Gerber. Cheltenham: Edward Elgar.

Belikova, Ksenia. 2016. General Approaches to Dominant Market Position, Prohibition of Abuse of Market Power, and Market Structure Control within the BRICS Countries. BRICS Law Journal III (1): 7-33.

Botta, Marco. 2010. The Brazilian senate passes the text of the new competition act introducing a more efficient merger control system. e-Competitions Bulletin 35224.

Casagrande, Paulo Leonardo. 2014. The new Brazilian competition law-two years on. CPI Antitrust Chronicle 1: 1-9.

Cengiz, Firat. 2013. The Modernisation of the EU Competition Law Regime: Institutional Design Lessons for China? In The Chinese anti-monopoly law: New developments and empirical evidence, ed. Michael Faure, and Xinzhu Zhang, 281-300. Cheltenham: Edward Elgar.

Competition Commission of India. 2015. Annual report on competition policy developments in India (2014-2015). http://www.cci.gov.in/annual-reports. Accessed: 10 Dec 2016.

De Carvalho, Vinicius Marques. 2012. Brazil: Regulator's Introduction. In Competition Law in the BRICS Countries, ed. Adrian Emch, Jose Regazzini, and Vassily Rudomino, 3-11. Alphen an den Rijn: Kluwer Law International.

De Carvalho, Vinicius Marques. 2015. Questions \& Answers. In Overview of competition law in Brazil, ed. Cristianne Zarzur, Krisztian Katona, and Mariana Villela, 25-40. São Paulo: IBRAC.

Davis, Dennis, and Lara Granville. 2013. South Africa: The Competition Law System and the Country's Norms. In The design of competition law institutions: global norms, local choices, ed. Eleanor M. Fox, and Michael J. Trebilcock, 266-328. Oxford: Oxford University Press.

Deng, Zhisong. 2016. Public Enforcement of Antitrust Law in China: Perspective of Procedural Fairness. In Competition law enforcement in the BRICS and in developing countries, ed. Frederic Jenny and Yannis Katsoulacos, 135-148. Springer.

Emch, Adrian, Jose Regazzini, and Vassily Rudomino. 2012. Competition Law in the BRICS Countries. Alphen an den Rijn: Kluwer Law International.

Federal Anti-Monopoly Service. 2012. Report of the Federal Antimonopoly Service on competition policy in 2012. http://en.fas.gov.ru/international-cooperation/oecd/oecd-annual/. Accessed 10 Dec 2016.

Federal Anti-Monopoly Service. 2013. Annual Report on competition policy developments in the Russian Federation in 2013. http://en.fas.gov.ru/international-cooperation/oecd/oecd-annual/. Accessed 10 Dec 2016.

Federal Anti-Monopoly Service. 2014a. FAS Brochure. http://en.fas.gov.ru/netcat_files/File/buklet_ osen'\%20EN.pdf. Accessed 10 Dec 2016.

Federal Anti-Monopoly Service. 2014b. Report on competition policy in the Russian Federation in 2014. http://en.fas.gov.ru/international-cooperation/oecd/oecd-annual/. Accessed 10 Dec 2016.

Federal Anti-Monopoly Service. 2015. Report on competition policy in the Russian Federation in 2015. http://en.fas.gov.ru/international-cooperation/oecd/oecd-annual/. Accessed 10 Dec 2016.

Fox, Eleanor M. 2010. Antitrust and institutions: Design and change. Loyola University of Chicago Law Journal 41: 473-488.

Fox, Eleanor M., and Michael J. Trebilcock. 2013. The GAL Competition Project: The Global Convergence of Process Norms. In The design of competition law institutions: Global norms, local choices, ed. Eleanor M. Fox, and Michael J. Trebilcock. Oxford: Oxford University Press.

Gal, Michal S. 2010. When the going gets tight: Institutional solutions when antitrust enforcement resources are scarce. Loyola University of Chicago Law Journal 41: 417-441. 
Gao, Shiji, and Yan Wan. 2013. Market, Regulation and State-Building in China. In The Chinese AntiMonopoly Law: New Developments and Empirical Evidence, ed. Michael Faure, and Xinzhu Zhang, 167-193. Cheltenham: Edward Elgar.

Gaur, Seema. 2012. India: Regulator's Introduction. In Competition Law in the BRICS Countries, ed. Adrian Emch, Jose Regazzini, and Vassily Rudomino, 101-109. Alphen an den Rijn: Kluwer Law International.

Global Competition Review. 2015. Global Competition Review Rating Enforcement 2015. http://www. autoritedelaconcurrence.fr/doc/star_ratings_gcr.pdf. Accessed 10 Dec 2016.

Guzman, Andrew. 2004. The case for international antitrust. Berkeley Journal of International Law 22 (3): 355-374.

Jenny, Frederic. 2016. The Institutional Design of Competition Authorities: Debates and Trends. In Competition law enforcement in the BRICS and in developing countries, ed. Frederic Jenny and Yannis Katsoulacos, 1-57. Springer.

Jenny, Frederic and Yannis Katsoulacos. 2016. Competition law enforcement in the BRICS and in developing countries. Springer.

Jones, Clifford A. 2000. Toward global competition policy? The expanding dialogue on multilateralism. World Competition Law and Economics Review 23 (2): 95-99.

International Competition Network. 2016. Competition Agency Evaluation. http://www. internationalcompetitionnetwork.org/uploads/library/doc1072.pdf. Accessed: 10 Dec 2016.

Kaczorowska-Ireland, Alina. 2014. Competition Law in the CARICOM Single Market and Economy. New York: Routledge.

Kovacic, William. 2012. Competition Law in the BRICS Countries: More than an Acronym. In Competition Law in the BRICS Countries, ed. Adrian Emch, Jose Regazzini, and Vassily Rudomino, 315-325. Alphen an den Rijn: Kluwer Law International.

Kovacic, William, and David Hyman. 2012. Competition agency design: What's on the menu? European Competition Journal 8 (3): 530-532.

MOFCOM. 2014. Budget report of MOFCOM in fiscal year 2014. http://www.mofcom.gov.cn/article/ cwgongzuo/feiyqr/201404/20140400552592.shtml. Accessed 10 Dec 2016.

MOFCOM. 2016. Final accounts report of MOFCOM in fiscal year 2015. http://www.mofcom.gov.cn/ article/cwgongzuo/feiyqr/201607/20160701364099.shtml\#4. Accessed 10 Dec 2016.

Moraes, Diego Herrera. 2011. The Brazilian President approves the new competition law introducing substantive reforms to the national antitrust enforcement. e-Competitions Bulletin 42231.

National Development and Reform Commission. 2014. Budget report of NDRC in fiscal year 2014. http:// zfxxgk.ndrc.gov.cn/Attachment/国家发展和改革委员会2014年部门预算.pdf. Accessed 10 Dec 2016.

National Development and Reform Commission. 2016. Final accounts report of NDRC in fiscal year 2015. http://zfxxgk.ndrc.gov.cn/Attachment/\%E5\%9B\%BD\%E5\%AE\%B6\%E5\%8F\%91\%E5\%B1 \%95\%E6\%94\%B9\%E9\%9D\%A9\%E5\%A7\%94\%E9\%83\%A8\%E9\%97\%A8\%E5\%86\%B3\%E7\% AE\%97\%EF\%BC\%882015\%E5\%B9\%B4\%E5\%BA\%A6\%EF\%BC\%89.pdf. Accessed 10 Dec 2016.

OECD. 2003. Competition law and policy in South Africa: An OECD peer review. http://www.oecd.org/ daf/competition/prosecutionandlawenforcement/2958714.pdf. Accessed 10 Dec 2016.

OECD. 2005. OECD Guiding Principles for Regulatory Quality and Performance. http://www.oecd.org/ daf/competition/sectors/37318586.pdf. Accessed 10 Dec 2016.

OECD. 2013. Competition law and policy in the Russian Federation. http://www.oecd.org/daf/ competition/CompetitionLawandPolicyintheRussianFederation.pdf. Accessed 10 Dec 2016.

Orlanski, Leonardo Tomas. 2011. Searching for the basis of international convergence in competition law and policy. Global Antitrust Review 4: 7-47.

Ramburuth, Shan. 2012. South Africa: Regulator's Introduction. In Competition Law in the BRICS Countries, ed. Adrian Emch, Jose Regazzini, and Vassily Rudomino, 207-217. Alphen an den Rijn: Kluwer Law International.

Round, David K., and Ping Lin. 2012. Introduction: embracing competition in the world's second giant economy: China's 2008 Anti-Monopoly Law. Review of Industrial Organization 41: 1-6.

Sharma, Deepankar. 2016. Dimensions of Leniency Policies in BRICS: A Comparative Analysis of India, South Africa, Brazil and Russia. BRICS Law Journal III (2): 6-20.

State Administration for Industry and Commerce. 2015. Budget report of SAIC in fiscal year 2014. http:// www.saic.gov.cn/zwgk/zyfb/czzj/201404/P020140418378473416650.pdf. Accessed 10 Dec 2016. 
State Administration for Industry and Commerce. 2016. Final accounts report of SAIC in fiscal year 2015. http://www.saic.gov.cn/zwgk/zyfb/czzj/201607/P020160722497236545826.pdf. Accessed 10 Dec 2016.

Schaeffer, Fiona A., Luis Riesgo, S. Wade Angus, and Michael Culhane Harper. 2011. The Brazilian Parliament approves new competition law subject to prior significant vetoes. e-Competitions Bulletin 50121.

Schaeffer, Fiona A., Luis Riesgo, S. Wade Angus, and Michael Culhane Harper. 2011. Brazil's Congress approves a new competition law that significantly restructures the landscape of competition enforcement. e-Competitions Bulletin 50116.

Su, Jessica, and Xiaoye Wang. 2013. China: The Competition Law System and the Country's Norms. In The design of competition law institutions: Global norms, local choices, ed. Eleanor M. Fox, and Michael J. Trebilcock, 194-231. Oxford: Oxford University Press.

Sushkevich, Alexey G. 2004. Administrative reform in the Russian antimonopoly authority and modernization of Russian competition law. http://www.jftc.go.jp/eacpf/05/APECTrainingProgram August2004/russia.sushkevich.pdf. Accessed 10 Dec 2016.

Trebilcock, Michael J., and Edward M. Iacobucci. 2010. Designing Competition Law Institutions: Values, Structure, and Mandate. Loyola University of Chicago Law Journal 41: 455-471.

US-China Business Council. 2014. Competition policy and enforcement in China. https://www.uschina. org/sites/default/files/AML\%202014\%20Report\%20FINAL_0.pdf. Accessed 10 Dec 2016.

Waked, Dina I. 2008. Competition law in the developing world: The why and how of adoption and its implications for international competition law. Global Antitrust Review 1: 69-96.

Waller, Spencer Weber. 2010. Designing Better Institutions to Enforce Competition Law: A Symposium Introduction. Loyola University of Chicago Law Journal 41: 411-415.

Wise, Michael. 2004. Competition law and policy in South Africa. OECD Journal: Competition Law and Policy 5 (14): 7-69.

WTO. 2004. Doha Work Programme, Decision Adopted by the General Council on 1 August 2004, WT/ L/579. https://www.wto.org/english/tratop_e/dda_e/ddadraft_31jul04_e.pdf. Accessed 10 Dec 2016.

Zarzur, Cristianne, Krisztian Katona, and Mariana Villela. 2015. Overview of competition law in Brazil. Sao Paulo: IBRAC.

\begin{abstract}
Alexandr Svetlicinii is an Assistant Professor at the Faculty of Law of the University of Macau where he also serves as the Associate Programme Coordinator for the Master of International Business Law. Research interests include: comparative competition law, comparative private law, international trade law and alternative dispute resolution.
\end{abstract}

Juan-Juan Zhang is currently a PhD candidate at University of Macau, Faculty of Law. Ms. Zhang also holds a position of lecturer at the Faculty of Law and of researcher at the Centre of Latin American Studies at the Southwest University of Science and Technology (China). 